\title{
Analisis Korelasi Kondisi Fisik, Lingkungan Belajar, Kecerdasan Emosi dan Spiritual terhadap Tingkat Kelulusan Ujian Teori Respirasi
}

\author{
Slamet Sudi Santoso \\ Program Studi Kedokteran, Fakultas Kedokteran dan Kesehatan, Universitas Muhammadiyah Jakarta \\ Jl. K. H Ahmad Dahlan No. 1 Cirendeu, Ciputat, Tangerang Selatan. 15419 \\ Email: santohope2016@gmail.com
}

\begin{abstract}
ABSTRAK
Mutu atau kualitas lulusan dokter dapat dicapai melalui penguasaan keilmuan, keterampilan, dan perilaku lulusan dokter. Proses tersebut diharapkan menjadi salah satu penentu utama kualitas pelayanan asuhan medis kepada masyarakat. Begitu pentingnya proses penguasaan keilmuan, sehingga perlu diketahui faktor-faktor yang berhubungan dengan tingkat kelulusan ujian teori respirasi sebagai salah satu mata kuliah di pendidikan kedokteran. Hasil ujian seharusnya mampu menggambarkan kemampuan peserta didik dalam penguasaan keilmuan dan mengukur kemampuan mereka. Peneliti bertujuan untuk meneliti korelasi antara faktor lingkungan, kondisi fisik, kecerdasan emosi dan spiritual dan hubungannya dengan tingkat kelulusan ujian teori respirasi. Penelitian ini merupakan penelitian kuantitatif dengan menggunakan desain penelitian Cross Sectional. Sampel pada penelitian ini adalah mahasiswa semester V Program Studi Kedokteran Fakultas Kedokteran dan Kesehatan Universitas Muhammadiyah Jakarta (FKK UMJ) berjumlah 110 orang. Teknik sampel menggunakan Total Sampling. Inklusi dalam penelitian ini adalah mahasiswa yang mengikuti mata kuliah respirasi. Hasil analisis menunjukkan bahwa variabel kondisi fisik $(\mathrm{OR}=4.400 ; 95 \% \mathrm{CI}=1.779-10.760)$, kecerdasan emosi $(\mathrm{OR}=3.926 ; 95 \% \mathrm{CI}=1.613$ - 9.554) dan kecerdasan spiritual $(\mathrm{OR}=2.386,95 \% \mathrm{CI}=1.105-5.153)$ berpengaruh signifikan terhadap tingkat kelulusan ujian teori respirasi mahasiswa FKK UMJ dengan pvalue kurang dari $0.05(\mathrm{p}<0.05)$ dan risiko terbesar pada variabel kondisi fisik. Variabel kondisi lingkungan belajar tidak berhubungan dengan tingkat kelulusan ujian teori respirasi dengan pvalue lebih dari 0.05 .
\end{abstract}

Kata kunci: lingkungan belajar; kecerdasan emosi; kecerdasan spiritual; tingkat kelulusan

The quality of doctor can be achieved through the scientific mastery, skills and behavior of doctor. The process is expected to be one of the main determinants of quality medical care services to the community. The importance of the process of scientific mastery, therefore it have to be find out the factors associated with the passing rate of the respiratory theory exam as one of the courses in medical education. Test results should be able to describe the ability of learners in the scientific mastery and measure their ability. The researcher aims to examine the correlation between environmental factors, physical condition, emotional and spiritual intelligence and their relation to the passing rate of the respiratory theory exam. This research is a quantitative research using Cross Sectional design. The sample in this research is the students of Medicine and Health Faculty University of Muhammadiyah Jakarta (FKK UMJ), which is 110 students. Sample technique using Total Sampling. Inclusion in this study is students who follow the respiration course. The results showed that physical condition variables $(\mathrm{OR}=4.400,95 \% \mathrm{CI}=1.779-10.760)$, emotional intelligence $(\mathrm{OR}=3.926 ; 95 \% \mathrm{CI}=1.613-9.554)$ and spiritual intelligence $(\mathrm{OR}=2.386,95 \% \mathrm{CI}=1.105-5.153)$ have a significant effect on graduation level of respiration theory of FKK UMJ students with pvalue less than $0.05(\mathrm{p}<0.05)$ and the greatest risk to physical condition variable. The condition variable of the learning environment is not related to the graduation level of the respiratory theory exam with pvalue greater than 0.05 . 


\section{Pendahuluan}

Undang - Undang Republik Indonesia Nomor 20 Tahun 2013 tentang Pendidikan Kedokteran Pasal 4 menyatakan bahwa, salah satu tujuan Pendidikan Kedokteran adalah untuk menghasilkan Dokter yang berbudi luhur, bermartabat, bermutu, dan berkompeten. Mutu atau kualitas lulusan dapat dicapai melalui penguasaan keilmuan, keterampilan, dan perilaku lulusan dokter. Proses ini diharapkan menjadi salah satu penentu utama kualitas pelayanan asuhan medis kepada masyarakat ${ }^{1}$. Penguasaan keilmuan merupakan satu-satunya faktor internal yang dapat dikendalikan oleh institusi pendidikan ${ }^{2}$. Salah satu bukti bahwa peserta didik menguasai keilmuan adalah dengan mengukur kemampuan mereka melalui ujian teori pada mata kuliah pendidikan dokter. Hasil ujian teori tersebut diharapkan mampu menggambarkan penguasaan keilmuan dan prestasi belajar peserta didik pada mata kuliah.

Terdapat banyak penelitian mengenai pengaruh IQ, motivasi dan strategi atau metode belajar terhadap tingkat kelulusan dan prestasi belajar. Dalam penelitian Sitompul menyatakan bahwa ada hubungan antara IQ dengan prestasi kognitif ${ }^{3}$. Penelitian Pranoto menunjukkan bahwa ada hubungan antara penerapan strategi pembelajaran dengan prestasi belajar ${ }^{4}$. Hasil penelitian lain oleh Rohmah ${ }^{5}$ menunjukkan bahwa terdapat hubungan positif dan signifikan antara motivasi belajar dengan prestasi belajar. Pada kenyataannya, faktor yang mempengaruhi penguasaan keilmuan atau prestasi belajar bukan hanya IQ, motivasi dan strategi belajar. Faktor - faktor lain yang juga mempengaruhi prestasi belajar dalam penelitian Riyani ${ }^{6}$ selain metode dan motivasi belajar adalah kondisi lingkungan dan kesehatan fisik. Faktor lain juga disebutkan dalam penelitian Iriani ${ }^{7}$ bahwa terdapat hubungan kecerdasan emosional dan spiritual dengan prestasi belajar.

$$
\text { Rita Mariyana menyatakan bahwa }
$$
lingkungan belajar merupakan sarana bagi siswa dapat mencurahkan dirinya untuk beraktivitas, berkreasi, hingga mereka mendapatkan sejumlah perilaku baru dari kegiatannya itu. Lingkungan belajar dapat diartikan sebagai tempat bagi siswa untuk bereksplorasi, bereksperimen dan mengekspresikan diri untuk mendapatkan konsep dan informasi baru sebagai wujud dari hasil belajar ${ }^{8}$. Lingkungan belajar yang baik seharusnya memberikan dukungan dalam berlangsungnya proses belajar atau pendidikan, sebaliknya lingkungan yang buruk adalah lingkungan yang memberi hambatan dalam proses belajar'. Kecerdasan spiritual adalah kecerdasan untuk menghadapi dan memecahkan persoalan makna kehidupan, nilai-nilai, dan keutuhan diri yaitu kecerdasan untuk menilai bahwa tindakan atau jalan hidup seseorang lebih bermakna dibandingkan dengan yang lain. Kecerdasan spiritual adalah landasan yang diperlukan untuk memfungsikan kecerdasan intelektual dan kecerdasan emosional secara efektif. Kecerdasan spiritual merupakan kecerdasan tertinggi ${ }^{10}$. Kecerdasan emosional menurut Daniel Golman adalah kemampuan mengenali perasaan kita sendiri 
Selamet Sudi Santoso. Analisis Korelasi Kondisi Fisik, Lingkungan Belajar, Kecerdasan Emosi dan Spiritual Terhadap Tingkat Kelulusan Ujian Teori Respirasi

DOI :

dan perasaan orang lain, kemampuan memotivasi diri sendiri dan kemampuan mengelola emosi dengan baik pada diri sendiri dan dalam hubungan dengan orang lain ${ }^{11}$. Sedangkan Steven J. Stein dan Howard E. Book dalam bukunya mendefinisikan kecerdasan emosional sebagai keadaan dimana individu mengetahui perasaan-perasaan yang baik dan buruk, dan bagaimana merubah yang buruk menjadi baik ${ }^{12}$.

Penelitian ini mengambil hasil ujian teori respirasi mahasiswa FKK UMJ dikarenakan persentase kelulusannya yang kecil yaitu hanya $27 \%$ yang berada di atas standar nilai kelulusan. Sisanya sebanyak 73\% masih dibawah standar nilai kelulusan FKK UMJ yaitu 56. Berdasarkan masalah diatas, peneliti bertujuan untuk meneliti korelasi antara faktor lingkungan, fisik, kecerdasan emosi dan spiritual dengan tingkat kelulusan ujian teori respirasi.

\section{Metode Penelitian}

Penelitian ini dilakukan di Program Studi Kedokteran Fakultas Kedokteran dan Kesehatan Universitas Muhammadiyah, dan merupakan penelitian kuantitatif dengan menggunakan desain penelitian Cross Sectional. Populasi dalam penelitian ini adalah seluruh mahasiswa Program Studi Kedokteran Fakultas Kedokteran dan Kesehatan Universitas Muhammadiyah Jakarta. Sampel pada penelitian ini adalah mahasiswa semester $\mathrm{V}$ berjumlah 110 orang. Teknik sampel menggunakan Total Sampling. Inklusi dalam penelitian ini adalah mahasiswa yang mengikuti mata kuliah respirasi.

Pengukuran variabel kondisi fisik, kondisi lingkungan, kecerdasan emosional dan spiritual dilakukan menggunakan kuesioner yang dirancang berdasarkan definisi variabel dan dilakukan validitas kuesioner. Analisis data dilakukan menggunakan SPSS 17.0. Analisis terdiri dari analisis univariat dan bivariat. Analisis univariat dilakukan untuk mendeskripsikan setiap variabel. Analisis bivariat untuk melihat hubungan antara semua variabel independen (kondisi fisik, kondisi lingkungan, kecerdasan emosional dan kecerdasan spiritual) dengan variabel dependen (Kelulusan Teori Respirasi).

\section{Hasil}

Hasil distribusi frekuensi responden menunjukkan proporsi mahasiswa berdasarkan kondisi fisik dan kondisi lingkungan belajar. Mahasiswa dengan kondisi fisik yang baik sebesar $40.9 \%$, dan dengan kondisi fisik buruk sebesar $59.1 \%$. Berdasarkan kondisi lingkungan belajar, mahasiswa dengan kondisi lingkungan belajar yang baik sebesar $62.7 \%$ dan $37.3 \%$ berada pada kondisi lingkungan yang buruk. 
Tabel 1. Distribusi Frekuensi Responden Berdasarkan Kondisi Fisik dan Lingkungan Belajar

\begin{tabular}{lcccc}
\hline \multirow{2}{*}{ Variabel } & \multicolumn{2}{c}{ Kondisi Fisik } & \multicolumn{2}{c}{$\begin{array}{c}\text { Kondisi Lingkungan } \\
\text { Belajar }\end{array}$} \\
\cline { 2 - 5 } & $\mathbf{n}$ & $\mathbf{\%}$ & $\mathbf{n}$ & \% \\
\hline Buruk & 65 & 59,1 & 41 & 37,3 \\
\hline Baik & 45 & 40,9 & 69 & 62,7 \\
\hline Total & 110 & 100 & 110 & 100 \\
\hline
\end{tabular}

Tabel 2 merupakan hasil distribusi frekuensi responden berdasarkan kecerdasan emosi dan kecerdasan spiritual. Mahasiswa dengan kecerdasan emosi diatas rata-rata sebesar $42.7 \%$. Mahasiswa dengan kecerdasan spiritual diatas rata-rata sebesar $45.5 \%$.

Tabel 2. Distribusi Frekuensi Responden Berdasarkan Kecerdasan Emosi dan Spiritual

\begin{tabular}{lcccc}
\hline \multirow{2}{*}{ Variabel } & \multicolumn{2}{c}{$\begin{array}{c}\text { Kecerdasan } \\
\text { Emosional }\end{array}$} & \multicolumn{2}{c}{$\begin{array}{c}\text { Kecerdasan } \\
\text { Spiritual }\end{array}$} \\
\cline { 2 - 5 } & $\mathbf{n}$ & $\%$ & $\mathbf{n}$ & $\%$ \\
\hline Dibawah Rata-Rata & 63 & 57,3 & 60 & 54,5 \\
\hline Diatas Rata-Rata & 47 & 42,7 & 50 & 45,5 \\
\hline Total & 110 & 100 & 110 & 100 \\
\hline
\end{tabular}

Tabel 3 merupakan hasil analisis bivariat mengenai hubungan kondisi fisik, lingkungan belajar, kecerdasan emosi dan spiritual terhadap tingkat kelulusan ujian teori respirasi. Hasil analisis tersebut menunjukkan bahwa kondisi lingkungan belajar tidak berhubungan dengan tingkat kelulusan ujian teori respirasi, sedangkan kondisi fisik, kecerdasan emosi dan spiritual memiliki hubungan yang signifikan. Hal ini dibuktikan dengan nilai pvalue pada kondisi lingkungan belajar lebih dari $0.05(\mathrm{p}=>0.05)$ yaitu 0.825 . Pada variabel kondisi fisik, mahasiswa yang memiliki kondisi fisik buruk berisiko 4.4 kali lebih besar tingkat kelulusan ujian teori respirasinya berada dibawah rata-rata dibanding siswa yang memiliki kondisi fisik baik $(\mathrm{OR}=4.400 ; 95 \% \mathrm{CI}=1.779$ - 10.760). Pada variabel kecerdasan emosi, mahasiswa yang memiliki kecerdasan emosi dibawah ratarata berisiko 3.9 kali tingkat kelulusannya berada dibawah rata-rata $(\mathrm{OR}=3.926 ; 95 \%$ $\mathrm{CI}=1.613$ - 9.554) dibanding mahasiswa yang memiliki kecerdasan emosi diatas rata-rata. Mahasiswa dengan kecerdasan spiritual dibawah rata-rata $(\mathrm{OR}=2.386,95 \% \mathrm{CI}=1.105$ 5.153 ) berisiko 2.7 kali lipat memiliki tingkat kelulusan dibawah rata-rata dibanding mahasiswa dengan kecerdasan spiritual diatas rata-rata. 
Selamet Sudi Santoso. Analisis Korelasi Kondisi Fisik, Lingkungan Belajar, Kecerdasan Emosi dan Spiritual Terhadap Tingkat Kelulusan Ujian Teori Respirasi DOI :

Tabel 2. Hubungan Kondisi Fisik, Lingkungan Belajar, Kecerdasan Emosi dan Spiritual Terhadap Tingkat Kelulusan Ujian Teori Respirasi

\begin{tabular}{|c|c|c|c|c|c|c|c|c|}
\hline \multirow{3}{*}{ Variabel } & \multicolumn{4}{|c|}{$\begin{array}{c}\text { Tingkat Kelulusan Ujian } \\
\text { Teori Respirasi }\end{array}$} & \multirow{3}{*}{ Pvalue } & \multirow{3}{*}{ OR } & \multicolumn{2}{|c|}{$95 \% \mathrm{CI}$} \\
\hline & \multicolumn{2}{|c|}{$\begin{array}{c}\text { Dibawah } \\
\text { Rata-Rata }\end{array}$} & \multicolumn{2}{|c|}{$\begin{array}{c}\text { Diatas Rata- } \\
\text { Rata }\end{array}$} & & & Lower & Upper \\
\hline & $\mathbf{n}$ & $\%$ & $\mathbf{n}$ & $\%$ & & & & \\
\hline \multicolumn{9}{|l|}{ Kondisi Fisik } \\
\hline Buruk & 55 & 84,6 & 10 & 15,4 & $0,001 *$ & 4,400 & 1,799 & 10,760 \\
\hline Baik & 25 & 55,6 & 20 & 44,4 & & & & \\
\hline \multicolumn{9}{|c|}{ Kondisi Lingkungan Belajar } \\
\hline Buruk & 29 & 70,7 & 12 & 29,3 & 0,825 & 0,853 & 0,361 & 2,081 \\
\hline Baik & 51 & 73,9 & 18 & 26,1 & & & & \\
\hline \multicolumn{9}{|l|}{ Kecerdasan Emosi } \\
\hline Dibawah Rata-Rata & 53 & 84,1 & 10 & 15,9 & $0,002 *$ & 3,926 & 1,613 & 9,554 \\
\hline Diatas Rata-Rata & 27 & 57,4 & 20 & 42,6 & & & & \\
\hline \multicolumn{9}{|l|}{ Kecerdasan Spiritual } \\
\hline Dibawah Rata-Rata & 49 & 81,7 & 11 & 18,3 & $0,031 *$ & 2,730 & 1,146 & 6,505 \\
\hline Diatas Rata-Rata & 31 & 62,0 & 19 & 38,0 & & & & \\
\hline
\end{tabular}

*Hubungan signifikan ( $\mathrm{p}$ value $<0,05$ )

\section{Pembahasan}

Hasil analisis bivariat dari empat variabel yang diteliti, terdapat tiga variabel yang terbukti berhubungan dengan tingkat kelulusan ujian teori respirasi mahasiswa. Variabel kondisi fisik berhubungan secara bermakna dengan tingkat kelulusan $(\mathrm{p}<0.05)$. Mahasiswa yang memiliki kondisi fisik buruk akan berisiko 4.4 kali lebih besar tingkat kelulusan ujian teori respirasinya berada dibawah rata-rata dibanding siswa yang memiliki kondisi fisik baik. Hal ini disebabkan kondisi fisik mempengaruhi konsentrasi dalam proses belajar, kondisi fisik yang baik dapat menghasilkan konsentrasi yang baik begitupun sebaliknya. Hal ini didukung oleh penelitian sebelumnya yang menyatakan kondisi fisik dapat mempengaruhi proses belajar yang berdampak pada prestasi atau hasil belajar ${ }^{13}$.
Tingkat kelulusan mahasiswa berhubungan pula secara bermakna $(p<0.05)$ pada mahasiswa yang memiliki kecerdasan emosi dan kecerdasan spiritual diatas rata-rata. Mahasiswa yang memiliki kecerdasan emosi dibawah rata-rata akan berisiko 3.9 kali tingkat kelulusannya berada dibawah rata-rata. Mahasiswa dengan kecerdasan spiritual dibawah rata-rata akan berisiko 2.7 kali lipat memiliki tingkat kelulusan dibawah rata-rata, dibanding mahasiswa dengan kecerdasan emosi dan spiritual diatas rata-rata. Hasil penelitian ini sejalan dengan penelitian yang dilakukan oleh Ni Kadek yang menyatakan bahwa kecerdasan emosional berpengaruh positif pada tingkat pemahaman atau penguasaan keilmuan dengan signifikansi dibawah 0.05 . Kecerdasan emosional seseorang memungkinkan orang tersebut memutuskan dalam situasi seperti apa dirinya berada lalu dapat menentukan 
bagaimana bersikap secara tepat didalamnya ${ }^{14}$. Mahasiswa dengan kecerdasan emosi yang baik akan memiliki motivasi untuk terus memahami sesuatu sehingga dapat mengatur dirinya untuk fokus pada tujuan yaitu memahami suatu pelajaran atau mata kuliah. Hal ini juga dikemukakan oleh penelitian Husnurrosyidah bahwa kecerdasan emosi dan spiritual berpengaruh terhadap tingkat pemahaman dengan mediasi kecerdasan adversitas ${ }^{15}$. Kecerdasan spiritual adalah kecerdasan seseorang dalam memaknai bagaimana arti dari kehidupan serta memahami nilai dari setiap perbuatan yang dilakukan dan kemampuan potensial setiap manusia yang menjadikan seseorang dapat menyadari dan menentukan makna, nilai, moral, serta cinta terhadap kekuatan yang lebih besar dan sesama makhluk hidup. Meskipun tidak secara langsung penelitian tersebut berdampak pada tingkat kelulusan suatu mata kuliah, namun peneliti menganggap bahwa salah satu bukti bahwa seseorang memahami atau menguasai keilmuan adalah dengan mengukur kemampuan mereka melalui ujian pada mata kuliah tersebut. Berbeda dengan hasil penelitian Alvis yang menyatakan bahwa kecerdasan emosi dan spiritual tidak berpengaruh terhadap prestasi belajar seseorang ${ }^{16}$. Hal ini mungkin dikarenakan perbedaan dalam menggunakan desain studi, atau adanya faktor lain yang lebih berpengaruh terhadap pemahaman atau prestasi belajar seseorang melalui analisis yang lebih mendalam.

$$
\text { Lingkungan belajar merupakan }
$$

variabel yang tidak berhubungan dengan tingkat kelulusan ujian teori respirasi pada penelitian ini. Hal ini disebabkan nilai pvalue pada variabel kondisi lingkungan belajar lebih dari $0.05(\mathrm{p}>0.05)$ yaitu 0.825 . Hasil penelitian ini bertolak belakang dengan hasil penelitian yang menyatakan bahwa lingkungan belajar berpengaruh secara signifikan terhadap prestasi belajar ${ }^{17,18}$. Penelitian lain juga menyebutkan bahwa ada pengaruh positif antara lingkungan belajar dengan prestasi belajar, meskipun hanya sebesar $7.3 \%$ dan sisanya dipengaruhi oleh variabel lain ${ }^{19}$. Hal ini disebabkan sebesar $69 \%$ mahasiswa merasa telah pada lingkungan belajar yang baik, sehingga hal ini tidak berpengaruh pada proses belajar serta prestasi belajar mereka.

\section{Kesimpulan dan Saran}

Hasil analisis menunjukkan bahwa kondisi lingkungan belajar tidak berhubungan dengan tingkat kelulusan ujian teori respirasi, dengan nilai pvalue lebih dari $0.05(\mathrm{p}>0.05)$ yaitu 0.825. Variabel kondisi fisik $(\mathrm{OR}=4.400$; $95 \% \mathrm{CI}=1.779$ - 10.760), kecerdasan emosi $(\mathrm{OR}=3.926 ; \quad 95 \% \mathrm{CI}=1.613 \quad-\quad 9.554)$ dan kecerdasan spiritual $(\mathrm{OR}=2.386,95 \% \mathrm{CI}=1.105$ - 5.153) berpengaruh signifikan terhadap tingkat kelulusan ujian teori respirasi mahasiswa FKK UMJ dengan pvalue kurang dari $0.05(\mathrm{p}<0.05)$ yaitu $0.001,0.002,0.031$ dengan risiko terbesar pada variabel kondisi fisik.

Saran dalam penelitian ini yaitu agar institusi dalam hal ini Fakultas Kedokteran dan Kesehatan Universitas Muhammadiyah Jakarta dapat memberikan pendampingan terutama 
Selamet Sudi Santoso. Analisis Korelasi Kondisi Fisik, Lingkungan Belajar, Kecerdasan Emosi dan Spiritual Terhadap Tingkat Kelulusan Ujian Teori Respirasi DOI :

dalam hal kecerdasan emosi, kecerdasan spiritual dan upaya-upaya mempertahankan kondisi fisik mahasiswa yang baik seperti mengadakan senam rutin bersama mahasiswa, konseling proses belajar mengajar dan muhasabah atau kajian mengenai keilmuan agama untuk mahasiswa.

\section{Daftar Pustaka}

1. Presiden Republik Indonesia. UndangUndang Republik Indonesia Nomor 20 Tahun 2013 Tentang Pendidikan Kedokteran. 2013.

2. Konsil Kedokteran Indonesia. Standar Pendidikan Profesi Dokter. Jakarta: Konsil Kedokteran Indonesia; 2012. 1$26 \mathrm{p}$.

3. Sitompul L. Hubungan Kecerdasan (IQ) dengan Hasil Belajar Kognitif Biologi di Kelas X MAN 2 Padang Sidimpuan. Logaritma. 2016;IV(1):37-49.

4. Pranoto MAS. Hubungan Penerapan Strategi Pembelajaran dengan Prestasi Belajar Peserta Didik di LBB Primagama Kabupaten Lamongan. E J UNESA. 2016;5(1):1-9.

5. Rohmah HNF. Hubungan anatara motivasi belajar denga prestasi belajar mata kuliah ASKEB 3 mahasiswa Prodi D IV Kebidanan FK UNS tahun jaran 2009/2010. 2010.

6. Riyani Y. Faktor-Faktor yang Mempengaruhi Prestasi Belajar Mahasiswa. J EKSOS [Internet]. 2012;8(1):19-25. Available from: http://repository.polnep.ac.id/xmlui/bits tream/handle/123456789/354/03-YANI R.pdf?sequence $=1$

7. Iriani Rampisela D, Rompas S, Malara R. Hubungan Kecerdasan Emosional dan Kecerdasan Spiritual dengan Prestasi Belajar Siswa di SMP Katolikst Fransiskus Pineleng. E-Journal Keperawatan. 2017;5(1).

8. Rita Mariyana. dkk. Pengelolaan Lingkungan Belajar. Jakarta: Kencana Media Group; 2010. 4 p.

9. Sukmadinata NS. Landasan Psikologi Proses Pendidikan. Bandung: PT. Remaja Rosdakarya; 2007.
10. Zohar, Marshal. SQ Memanfaatkan kecerdasan Spiritual dalam Berpikir Integralistik dan Holistik untuk Memaknai Kehidupan. Bandung: Mizan Media Utama; 2001.

11. Daniel Goleman. Emotional Intelligence. 10th Anniv. New York, United States: Random House USA; 2006.

12. Steven J. Stein dan Howard E. The EQ Edge: Emotional Intelligence and Your Success Paperback. Jossey-Bass;

13. Anggresta V. Analisis Faktor-Faktor yang Mempengaruhi Prestasi Belajar Mahasiswa Fakultas Ekonomi Universitas Negeri Padang. J Econ Econ Educ. 2016;4(1).

14. Rusmiani NKA. Pengaruh Kecerdasan Emosional, Kecerdasan Intelektual dan Perilaku Belajar pada Tingkat Pemahaman Akuntansi. J Akunt Univ Udayana. 2017;20(2):959-85.

15. Husnurrosyidah, Rahmawaty A. Pengaruh kecerdasan emosional dan kecerdasan spiritual terhadap pemahaman akuntansi syariah dan kecerdasan adversitas sebagai variabel mediasi. Equilib (Jurnal Ekon Syariah). 2015;3(2):199-220.

16. Dewanto AM, Nurhayati S. Kecerdasan Spiritual Terhadap Sikap Etis dan Prestasi Mahasiswa Akuntansi (Studi Pada Perguruan Tinggi di Kota Pekalongan). 2009;(1). Available from: jurnal.unikal.ac.id/index.php/pena/artic le/viewFile/72/72

17. Kartika DT. Pengaruh Cara Belajar dan Lingkungan Sekolah Terhadap Hasil Belajar IPS Ekonomi Pada Siswa Kelas VIII SMP N 2 Bonjol. 2011;1-15.

18. Mifthahurrachman MS. Pengaruh Lingkungan Belajar terhadap Prestasi Belajar Akuntansi dengan Kecerdasan Emosional sebagai Variabel Moderating. J Pendidik Akuntasi Indones. 2015;13(1):10-9.

19. Ariwibowo MS. Pengaruh Lingkungan Belajar terhadap Prestasi Belajar Mahasiswa PPKn Angkatan 2008 / 2009 Universitas Ahmad Dahlan Semester Ganjil Tahun Akademik 2010 / 2011. J Citizsh. 2012;1(2):113-22. 